\section{Zaklina Spalevic ${ }^{1}$}

Singidunum University

Milos Ilic ${ }^{2}$

University of Pristina, Faculty of Technical Science,

Kosovska Mitrovica

Dusan Jerotijevic ${ }^{3}$

Universiti Union ,Nikola” Tesla

Faculty of Business and Industrial Management
SCIENTIFIC REVIEW ARTICLE doi:10.5937/ekonomika1604155S

Received: March, 2016 Accepted: November 18, 2016

\title{
ELECTRONIC MONITORING DEVICES AND DATA PROCESSING
}

\begin{abstract}
Criminal justice authorities may wish to monitor or to control the location of particular person without resorting to imprisonment. An electronic monitoring device provides pretrial services, probation, or parole the chance to closely supervise convicted person by keeping track of where person are at or in some cases, determine if convicted person is consuming prohibited substances like alcohol or narcotics. Some systems provide tracing within predefined restricted areas. Systems like this are in use for different situations, for example before a criminal trial or after conviction. Authors described different ankle monitor systems that are in use, their advantages, disadvantages and data that collects. For each convicted person data from electronic monitor device is very important. Authors described machine learning method, which based on data could predict whether the convicted person will repeat the criminal offense or not. Methods like this works with hypothesis and gradient descent. At the end authors explored the role of these devices by the law of enforcement sanctions and measures outside the prison.
\end{abstract}

Key words: Ankle monitor, House arrest, Machine learning, Prediction, GPS monitoring.

JEL classification: O31,C89,C60

\section{УРЕБАЈИ ЗА ЕЛЕКТРОНСКО ПРАЋЕЊЕ И ОБРАДА ПРИКУПЉЕНИХ ПОДАТАКА}

\section{Апстракт}

Установе за извршење кривичних санкиија имају потребу да врше мониторинг и контролу кретања појединих осуђеника који казну служе ван затвора. Уређаји

\footnotetext{
${ }^{1}$ zspalevic@singidunum.ac.rs

${ }^{2}$ milos.ilic@pr.ac.rs

${ }^{3}$ dusanjerotijevic@gmail.com
} 
за електронско праћење пружају особљу задуженом за праћење оваквих осуђеника податке о томе где се осуђеник налази, његовој путањи кретања, или у појединим случајевима информачије о томе да ли осуђеник конзумира забрањене супстанце као што су алкохол или наркотищи. Неки системи обезбеђују праћење у оквиру унапред дефинисаних и ограничених подручја, и могу се користити у ситуацијама праћења особе пре суђења или током извршења казне. Аутори у раду описују различите системе електронских уређаја за праћење (наногица), юихове предности и мане, као и податке који се са юих могу прикупьати. 3 а свако осуђено лище подащи са овакивх уређаја су веома битни. У раду је описан и метод заснован на машинском учењу који на основу података може вриити предикиију да ли ће осуђено лице поновити исто кривично дело. Овакви методи раде на принципухипотеза и градиент десцент-а. На крају аутори суистражсили примену оваквих уређаја у пракси према Закону о извршењу ванзатворских санкција и мера.

Кључне речи: Наногица, Кућни притвор, Машинско учење, Предикција, ГПС праћене.

\section{Introduction}

Every year a large number of criminals are being sent to prison. Prisons are expensive to build and run, and often involve cruel treatment of fellow citizens, possibly contributing to the conversion of inmates into hardened criminals. That is why alternatives to imprisonment are one of important development area. One of the most intriguing experiments in this area is the substitution of incarceration for electronic monitoring (Rafael \& Ernesto, 2013). In an increasingly mobile world, house arrest ankle bracelets have many practical purposes. They're most commonly used to monitor the movements and behaviors of repeat drug and impaired-driving offenders serving active sentences of probation. Another problem that is particularly solved with usage of ankle bracelets are overcrowded prisons. Most states offer convicts the option to wear an ankle bracelet during a period of supervised probation in lieu of spending time in prison. Electronic monitoring is one possible solution for prevention of convicted person to repeat criminal acts (Matt \& Russell). In order to address problem, twenty-four hours monitoring must be provided. Electronic monitoring systems are collecting an enormous number of data for each convicted person. These data can be used for various observation and assessment of risk. Only authorized personnel can manage and use this data.

One probation officer has many convicted citizen in his jurisdiction, and his obligation is to track them and analyze data collected from the field. Some of convicted persons will repeat the criminal offense, that's for sure. The job of employees in control centers is to predict which of electronic monitored convicted persons could be in situation to repeat the same offense. In order to prevent that, and based on all collected data from electronic monitoring system, they must predict the future behavior for each convicted person. As a result from research, authors had proposed a machine learning algorithm. This algorithm is based on learning set of data, and purpose is to predict whether the monitored offenders will repeat criminal offence or not, based only on the current set of data for monitoring offenders. Learning set of data (data from the past), are in use for prediction model creation. Based on those data, machine learning algorithm will be trained for future predictions. Data from the 
current moment are in use for comparison with data from the past and based on that fact prediction will be made. Adequate prediction can prevent re-commit a criminal offense.

\section{Types of Electronic Monitoring Systems}

Electronic ankle bracelets are often used for community corrections efforts. They are often used in conjunction with a radio frequency base unit which is connected to a traditional telephone line. The reports sent by the base unit over the phone are usually monitored by a third-party contractor, although in some jurisdictions law enforcement agencies take care of this function. There are several types of electronic monitoring devices that are commonly used (Hilf \& Hilf, 2015).

GPS (Global Positioning System) tether - allows a defendant's movements to be tracked and reported to the suitable supervising agency. Hot zones are preset into a computer program that runs in combination with the GPS tether that alert authorities whenever the defendant goes someplace that is forbidden. GPS tethers are common for persons charged or convicted of criminal sexual assault, domestic violence, stalking, or other crimes that involve a victim. In order to be eligible for a GPS tether, the defendant must have a stable address and electricity at the address. Usually if this is ordered the defendant is not released from custody until the GPS tether is set up and functioning, and the alleged victim is notified as to the defendant being released on tether. Example of GPS tether is ExacuTrack One. The anklemounted unit uses GPS and similar location monitoring technologies to precisely track a person's movement within local communities. It uses a combination of location technologies for improved trustworthiness in more challenging environments such as indoors, moving vehicles or among very tall buildings. The lightweight unit is rugged, tamper-resistant, and has an extensive battery life. An optional beacon system can be used in order to reduce operational expenses. The beacon is installed in designated locations, like the client's home, place of work, school or other. When the individual enters an area where a beacon is located, the system switches mode from GPS tracking to traditional radio-frequency monitoring. When the person exits the beacon range, the system immediately shifts back to GPS tracking. Unlike other GPS tracking systems, this system enables officers to select specific zones, which can be in any shape through Microsoft MapPoint and Bing Maps for Enterprise. These are industry-leading mapping technologies. The maps offer detail extraction, making specific features on properties or neighborhoods clearly visible. When alerts are spawned, officers can receive them via pager, e-mail, PDA or a combination of these methods. Controlling officers are also allowed to send pre-recorded voice messages to offenders through the tracking unit, which are beneficial for appointment reminders or for forbidden zone warnings. As a result of big number of limitations, there has been growing initiative for application of advanced GPS technologies as an alternative tool to enhance the supervision of community offenders (Lilly, 2006).

Transdermal alcohol tether - monitors the defendant's skin to determine his or her blood alcohol level. It is usually attached to his or her ankle by a bracelet. It also monitors whether attempts to bypass the system are made, based upon tampering with the equipment or a change in the defendant's body temperature. It is in use for alcohol defendant on probation, or home arrest. One example is SCRAMx ankle bracelet. The patented SCRAMx ankle bracelet is attached to the user with a robust and tamper-proof strap. It is worn $24 / 7$ by the user for the 
duration of his or her court-ordered abstinence period. Every half hour, the bracelet captures transdermal alcohol readings by sampling the insensible perspiration collected from the air above the skin. The bracelet stores the data and, at pre-determined intervals, transmits it via a wireless radio-frequency (RF) signal to the base station. During installation, a base station is plugged into an analog telephone line - usually in the user's home or place of work. At a pre-scheduled time(s) each day, bracelet communicates with the base station, which transmits alcohol readings, tamper alerts, and diagnostic data to SCRAMNET for detailed analysis and reporting. The base station also has an LCD screen that provides operation messages to the user (Barton, 2015). The range of a house arrest ankle bracelet can be between 3000 and 4000 sq. $\mathrm{ft}$. At timed intervals, the ankle monitor sends a radio frequency or GPS signal to a receiver. If an offender moves outside of an allowed area, the police will be notified. The major downside of this technology is that it is not unambiguous to ethyl alcohol, the type of alcohol that is consumed by people. There are other types of alcohol that can be found in every household, which the fuel cell will read and report as a possible drinking event. Isopropyl alcohol is an alcohol commonly found in cleaning products. Methanol alcohol is the primary ingredient in the fuel burned by engines. All of these alcohols, and others, will be detected by the SCRAM. The data that is generated by the fuel cell is interpreted exclusively by alcohol monitoring systems employees. They are the only people who are trained to determine if the alcohol readings are in fact the result of a drinking event or if the readings were caused by an interferential. They make their determinations and conclusions primarily based upon the analysis of available data, and of the graph that is created from that data.

\section{Data Processing From Electronic Monitors}

Various types of electronic monitoring devices have been developed over the years, with each successive generation improving upon its predecessors, both in terms of their functionality and convenience. Some electronic monitoring devices are relatively simple and use GPS technology to alert the authorities when their wearers deviate from a pre-planned route. Others are more complex, and designed to detect traces of alcohol or illegal drugs in the blood. In both cases, ankle bracelets can be powerful deterrents for convicts who might otherwise flout the terms of their probation sentences. Modern electronic monitoring devices are collecting data and sending them to the base station in some surveillance agency. Depending on the type of crime, different parameters from electronic monitors are collected and monitored. If we have GPS monitored convicted person the key parameter for that system is distance from the boundary of restricted area, or current position. For offenders that are in probation for physical assault, distance from the victim is crucial. For alcohol offenders key parameters are alcohol measurements. For determination if the alcohol readings are from a drinking event or not, experience of the employee is essential. The question is can computer based programs do monitoring and prediction for us?

For this task, first step is classification of data parameters collected by the same or similar offence. For some offender, prediction will be based on one parameter, but for other, prediction will depend on more than one parameter. In both cases machine learning method can be used. As in all machine learning methods accuracy of prediction depends on how big learning set is (Alex \& S.V.N, 2010). For this task hypothesis and cost function are defined in Eq. 1 and Eq. 2 respectively. 


$$
\begin{aligned}
& h_{\theta}(\mathrm{x})=\theta^{T} x=\theta_{0} x_{0}+\theta_{1} x_{1}+\theta_{2} x_{2}+\ldots+\theta_{n} x_{0} \\
& J\left(\theta_{0}, \theta_{1}, \ldots, \theta_{n}\right)=\frac{1}{2 m} \sum_{i=1}^{m}\left(\mathrm{~h}_{\theta}\left(\mathrm{x}^{(\mathrm{i})}\right)-\mathrm{y}^{(\mathrm{i})}\right)^{2}
\end{aligned}
$$

Here $\theta_{1}, \theta_{2}, \ldots, \theta_{n}$ are hypothesis parameters, and $x_{1}, x_{2}, \ldots, x_{n}$ are data from database based of which hypothesis provides an event. Parameters $\theta_{p}, \theta_{2}, \ldots, \theta_{n}$ are not individual parameter values, but parameters are represented by $n+1$ dimensional vector $\theta$. In Eq. 2 parameter $m$ represents number of training examples. Based on parameters representation, cost function will be represented with $J(\theta)$. Cost function defines data linear regression. Pseudo algorithm for gradient descent is represented in Eq. 3, and gradient descent minimizes cost function.

\section{Repeat \{}

$$
\theta_{j}:=\theta_{j}-\alpha \frac{\partial}{\partial \theta_{j}} J(\theta)
$$

Here is most important that parameters $\theta_{1}, \theta_{2}, \ldots, \theta_{n}$ must be simultaneously updated. Second part of Eq. 3, can be represented differently Eq. 4. In the previous equation, $\alpha$ represents learning rate (Spalevic, Ilic, \& Spalevic, 2015). Depend of that parameter, gradient descent will figurate as larger or smaller step in the minimization process.

$$
\frac{\partial}{\partial \theta_{j}} J(\theta)=\frac{1}{m} \sum_{i=1}^{m}\left(\mathrm{~h}_{\theta}\left(\mathrm{x}^{(\mathrm{i})}\right)-\mathrm{y}^{(\mathrm{i})}\right) x_{j}^{(\mathrm{i})}
$$

When we replace Eq. 4 in Eq. 3 we will get final algorithm for gradient descent Eq. 5. For this algorithm also valid that $\theta_{j}$ must be updated simultaneously for every $j$. Each step of gradient descent uses all the training examples.

Repeat \{

$$
\theta_{j}:=\theta_{j}-\alpha \frac{1}{m} \sum_{i=1}^{m}\left(\mathrm{~h}_{\theta}\left(\mathrm{x}^{(\mathrm{i})}\right)-\mathrm{y}^{(\mathrm{i})}\right) x_{j}^{(\mathrm{i})}
$$

If implementation does not simultaneously provide update, values for parameters at the end of algorithm will not be correct. Here is important that character $\mathrm{i}$ in the superscript for $x$ do not represents power, but index. With this index and index in the subscript the concrete data value from the database table will be used. Each $\theta_{j}$ parameter will be used in cost function calculation. After the cost function calculation, we must find minimal value for cost function, for given $\theta_{j}$ and for given hypothesis. Minimal cost function will provide best linear regression. In implementation, if we want to apply some hypotheses, that can be implemented like matrix and vector multiplication, in the case of just one hypothesis, or matrix and matrix multiplication if we have multiple hypotheses. In some cases if we have parameters of different sizes, some kind of scaling must be done. For example, we have two types of parameters, one in the range from zero to three hundred, and second in the range from one to seven. If we apply parameters like this we will get gradient descent that will provide 
a long time for calculation of minimal gradient descent value that can provide minimal cost function (Stephen, 2009). To prevent this all values in training samples for first parameters must be divided by the maximum value of the range, in our case with three hundred, and the second parameters must be divided with seven. This provides short time for gradient descent calculation. After calculation of the minimal value for gradient descent and minimization of cost function, cost function parameters and hypothesis representation can be compared. In the case of just one parameter there would be linear representation for hypothesis.

Cost function will be represented with some kind of. For more than two parameters cost function is much complicated - it will be represented in 3D. However, 2D presentation in the form of concentric circles can be used instead of 3D display type. In both cases minimization of cost function must be applied. Cost function minimization process provides a more accurate prediction and graphical representation.

\section{The Law of Enforcement Sanctions and Measures Outside The Prison}

In the case of outside the prison electronic monitoring sanctions, they are regulated and published in official Gazette RS, number 55/2014. This law regulates the procedure for sanctions execution outside prison and measures imposed in criminal, misdemeanor or other court proceedings, which are executed in the community. These sanctions are implemented in order to protect society from crime. This is provided by execution sanctions out of prison and measures in the community with the aim of re-socialization and reintegration of prisoners. The execution is carried out based on decision of the public prosecutor, the court or at the request of the Institute for criminal sanctions execution. Based on fifth article and depending on the criminal act, execution can be provided in different ways. By this act electronic monitoring can be used in different circumstances.

First, it can be used for home detention, and measures of prohibition approaching, meeting or communicating with a particular person. Second situation is home arrest. In this case electronic monitoring provides organization, implementation and monitoring execution of a sentence of imprisonment in premises where the convicted person resides. In the same time electronic monitoring can provide supervision of conditionally released person and support that respects the constraints that face a court. In this case electronic surveillance may not last longer than one year, nor more than probation.

If convicted person is in for home detention, the Court in its decision will indicate whether the measure of home detention is executed with or without the use of electronic supervision. The same decision must be indicated in the case of house arrest. Before making a decision on the execution of the sentence of house arrest with electronic surveillance application, the court shall determine whether there are technical and other possibilities for the execution of the sentence. If the court decides that the measure of house arrest is executed with the use of electronic surveillance, electronic surveillance equipment is activated immediately after delivery of the decision. A device for locating the defendant, that is safe for health, is set by expert, who is giving necessary instructions to the defendant on the method of operation of the device. Supervision agency manages the device that remotely monitors the movement of the defendant and his position in space. By this law convicted shall have the right to stay out of room in that house for a maximum of two hours a day over a period of 
thirteen to seventeen hours. By special decision convicted person may leave the premises in which resides in the some cases. For example, for providing necessary medical assistance, to go on work, exams, classes in the school, due to the death of a close relative, and etc. In the case of that the convicted abandons the premises in which resides a lasting over six hours or twice for up to six hours, trust service notifies the court that brought the verdict.

Based on this court, shall render a decision that convicted the rest of the prison sentence withstand in the Institute for the execution of imprisonment and ordered the issuance of arrest warrants. After this the command for issuing the arrest warrants is delivered to the police authorities for execution. By this law, time spent on the run will not be counted in the time of execution of the sentence. Law of enforcement sanctions and measures outside the prison in this form provides full use of electronic monitoring and data processing from electronic monitoring devices.

\section{Examples of electronic monitoring in use abroad}

The system of electronic monitoring in the Province of Buenos Aires started in December of 1997. Since its inception, and up until April 2007, more than 910 men had been at some point under electronic surveillance. The electronic monitoring system in the province of Buenos Aires consists of a bracelet worn in the ankle or wrist of the offender. The surveillance program is relatively small, with a capacity of handling a maximum of 300 detainees simultaneously (Tella \& Schargrodsky, 2009).

Electronic monitoring is currently available as a primary sentence in the United States and is generally considered to be somewhat more lenient than prison, but harsher than probation. Figures from the Bureau of Justice Statistics show that in 1998 there were 19,677 people on electronically monitored probation in the United States (Bonczar \& Glaze 1999). Restriction and surveillance can also be used to reduce the likelihood of the individual re-offending, particularly against the original victim. Today the number of convicted persons electronically surveiland is much bigger According to the Bureau of Justice Statistics more then five million offenders in the United States are under some form of community supervision. We can show court practice on one example from the superior court in North Carolina. In May 2013, this court ordered to the offender to submit to an involuntary GPS monitoring program. The hearing occurred four years after he was released from prison, where he had served time for a 2006 conviction for "indecent liberties with a child."(Brief, 2015) Though he was not in custody or on probation at the time of the hearing, the Department of Correction had determined that he was recidivist based partly on a 1997 conviction for second-degree sexual offense. Because he was found to be a "sexual offender" and a "recidivist," he was involuntarily placed in the state's Satellite-Based Monitoring Program (Bodi, 2015).

GPS ankle monitors are becoming standard equipment for immigration officials along the border, too. In July 2015, Immigration and Customs Enforcement, used about 9,300 ankle monitors at a time - 40\% more than about six months ago. They are run by a government contractor, BI Inc., a subsidiary of the country's second-largest prison company, which also operates immigration detention centers. Officials say the monitors are a cheap and effective way to ensure that immigrants released from detention attend court hearings. The monitors cost an average of $\$ 5$ a day per person, and are part of 
the agency's Alternatives to Detention program, which also may require immigrants to report by phone or in person. In contrast, detention costs an average of $\$ 130$ per day per person, and can cost over $\$ 330$ at some detention centers (Hennessy-Fiske, 2015). In this way the funds in the state budget can be significantly saved and increased. This provides benefits for both sides, the convicts and the state.

Government services in Florida evaluated the electronic monitoring system, which was approved for use by the Florida Department of Corrections in 1987. In their evaluation of the electronic monitoring system in Florida thay found that, compared with the control group on other forms of community supervision, electronic monitoring reduced the risk of failure to comply by $31 \%$. GPS was slightly more effective in reducing rates of failure to comply than radio frequency systems; more specifically, for GPS monitoring there was a $6 \%$ improvement in the hazard rate for reducing supervision failure compared with radio frequency monitoring. Electronic monitoring made deeper impacts on sex, property, drug, and other types of offenders than on violent offenders, though the effects remained significant for this kind of supervision of violent offenders compared with other forms of community supervision. There were no significant differences in the effects of electronic monitoring across different age groups or for the effect of electronic monitoring for different types of supervision. However, notably, although juveniles were included in the study, the majority of participants were adults (Bales et al. 2010).

In Sweden, intensive supervision with electronic monitoring is not absent within the correctional system. As a form of serving prison terms at home, the measure replaces the enforcement of imprisonment up to three months. The main target group consists of severely drunken drivers who have been traditionally sentenced to short prison sentences (Haverkamp, 2002). The crucial point lies in the caring work of the probation service. This method should guarantee a more human way of the serving at home according to the intention of the legislator. Intensive supervision helps to remove capacity problems in open prisons and to save money by closing down prisons. In Sweden, approximately 3000 convicted persons serve their prison term at home every year.

Electronic monitoring bail scheme was introduced in New Zealand at September 2006, and it was initially managed entirely by New Zealand Police. From the February 2014 the Department of Corrections and police are jointly managing electronic monitoring bail under a shared service model. Electronic monitoring on bail is available for suitable defendants and young people (12- 17 years of age) who would otherwise continue to be held in custody, in prison, or in the instance of a young person in a youth residence, while they wait for a court hearing. A significant change sees police no longer having electronic monitoring bail assessors in the field after 1 February 2014. Instead, for all new applications, a probation officer will take the role of bail assessor and complete assessments electronic monitoring bail applicants, attend electronic monitoring bail connections and complete inductions with the bailees. The central team at corrections manages the 0800 electronic monitoring bail line, liaises with the monitoring company and is the central point of contact for electronic monitoring bailees. In all cirumstances bailees must contact the EM Bail Team at Corrections if they want to plan some time away from their approved address. The electronic monitoring bail team will tell them what thay need to do and what happens next. Bailees must contact this team at least three working days before any planned short-term absence. Approval is not automatic and will be at the discretion of the electronic monitoring bail team. Today two Australian 
jurisdictions have specific legislative authority for home detention with electronic monitoring as a primary sentencing option.

The Northern Territory's Sentencing Act 1995 provides that a court which sentences an offender to a term of imprisonment may make an order suspending the sentence on the offender entering into a home detention order. Offenders on a home detention order may be required to wear or have attached a monitoring device (Black \& Smith, 2003). In Western Australia, the Sentencing Act 1995 provides that a court may impose an intensive supervision order with a curfew requirement. This requires the offender to submit to surveillance or monitoring as ordered and to wear a device or have a device installed in his or her home. Electronic monitoring may only be imposed for a term of six months or less.

South Australian Department for Correctional Services chosee EM technology provider named G4S since the inception of the electronic monitoring system in South Australia (EMSSA) nearly 15 years ago. G4S was recently awarded a new contract that will run into 2017 and the service also includes monitoring of juveniles for the South Australian Department for families and social inclusion. The program, which covers both adult and juvenile offenders placed on court-ordered restrictions, utilises G4S's propriety GPS monitoring equipment to support monitoring and response tasks undertaken by the department for correctional services for around 450 offenders statewide, making it Australia's largest electronic monitoring program. G4S continues to develop Electronic Monitoring and to explore wider opportunities to expand, not only its traditional forms of $\mathrm{EM}$, but also in the areas of alcohol monitoring and domestic violence. G4S is justifiably proud of its South Australian achievements to date, including the sustained maintenance of ISO certification for Electronic Monitoring Services (G4S, 2016).

Electronic monitoring can save tax-payers, detention facilities, and adjudicated juveniles' money. For instance, EM programs help reduce the number of juvenile offenders who are placed in residential facilities. Financially, this makes a considerable difference as EM programs can range anywhere from $\$ 5.50$ to $\$ 10$ per day whereas detention centers can range from $\$ 100$ to $\$ 160$ per day. Taxpayers also reap the benefits, as juveniles on home confinement with or without electronic monitoring can work and essentially pay for their monitoring device. Finally, home confinement with or without electronic monitoring can also save the juvenile money, as his or her bond may be reduced if the youth agrees to home confinement and/or electronic monitoring (Sklaver 2010). After adopting an EM program in one county, the number of juveniles in detention centers decreased from 94 per day in 2003 to 45 per day - a 53\% decrease. Moreover, the public's tax burden is reduced as offenders are allowed to work and subsequently pay for the EM costs. EM programs can save the juvenile money as well, upon adjudication, a bond may be reduced if the juvenile agrees to submit to electronic monitoring.

Another advantage in that EM programs improve the chances of a successful rehabilitation for youths by allowing them to remain at home and continue attending school. One study yielded a 3\% recidivism rate for electronically monitored home detention cases, and in Tarrant County, Texas, 242 juveniles utilized the EM program with an $85 \%$ success rate in 2002. A report from 2004 shows that $75 \%$ of juveniles who were released from the EM program were considered successful in North Carolina. 


\section{Conclusion}

Number of people in the world rises every day. By statistics, number of convicted persons rises every day too. Many of them have job, families, social life, but they are convicted for some offence, and must be in prison for some time. Some of them have been sentenced for serious offence, and some of them for minor offenses. All of them share the same prisons. For the people that are returnees to the offenses, that is logical sentence, but for the people that are convicted for the first time, prison can be horrible experience, especially for ones that are sentenced for minor offence. Financially, prisons are expensive, and many countries do not have money for the proper maintenance of the prison buildings, guards and food for a large number of prisoners. Another approach mentioned above is electronic monitoring of convicted persons, persons on parole or monitoring in the pre-trial period. Use of electronic monitoring device is new term in criminal justice system, especially in our country. Systems like these are in use for a long time in many countries all over the world. Like we said above, those systems provide serving sentences in home environment, with family and without interrupting daily activities. From the social side this is very important, because people who serve sentence like this have chance for better life during the term of the sentence. These people can go the school, to the work and can behave like thay are not convicted. Their normal activities will not be compromised. This is important because many of these people are convicted for small offence as well as for failure to pay penalties or taxes.

From another side we must not forget that some of those people have committed a criminal offense. With electronic monitoring they are out of prison, and they can repeat the same or similar criminal offence. To prevent that, they must be monitored all the time. For that job officer must supervise the movement of convicted person, and, based on all parameters try to predict if he/her would repeat offence. This is complex job for which appropriate experience is needed. Authors presented their idea how the use of electronic monitoring devices, and processing of data collected from electronic monitoring devices. With those data, that are movement path, distance from the base station, distance from the restricted person, alcohol level, and possible drugs use, machine learning system which will predict future acts of convicted person could be created (Spalevic et al, 2015). System like this must be based on different kind of hypothesis and heuristic. In that way system will predict critical situation, and inform officer about it. For systems like these training samples must be used. That is not limitation because government services already have sufficiently available data, and data from each new convicted person how is electronically monitored can be used. In this way new data can be added to the training set, and could be used for future treaning of the prediction model.

For future research authors plan to implement system in the way that they've described here. For job like this database with data collected from electronic monitoring devices must be created. That means that real data from some surveillance agency or gonverment service will be used. For heuristic, cost function, gradient descent and prediction Mat Lab software will used. For data preprocessing, which means classification and clustering organization of collected data GUI framework will be created. Like we said above data processing and machine learning could provide much more from simple offenders monitoring, and that possibility need to be used. 


\section{References}

Bales, W., Mann, K., Blomberg, T., Gaes, G., Barrick, K., Dhungana, K., and McManus, B. (2010). A Quantitative and Qualitative Assessment of Electronic Monitoring. Tallahassee, Fla.: Florida State University, College of Criminology and Criminal Justice, Center for Criminology and Public Policy.

Barton, M. (2015). The scram tether, How it works and how it doesn't. Law Office of Barton Morise. Retrieved November 13, 2015, from: http://michigancriminalattorney.com/ scram-tether-works/.

Black, M, \& Smith R. (2003). Electronic monitoring in the criminal justice system. Australian Institute of Criminology, 254, 1-6.

Bodi, A. (2015). Monitoring for Life: Satellite Surveillance of Ex-Offenders, American Criminal Law Review, Retrieved January 20, 2016, from: .

Bonczar, T. \& Glaze, L.E. (1999). Correctional Populations in the United States, 1998, Bureau of Justice Statistics, US Department of Justice, Washington DC.

Brief for Respondent at 1, Grady v. North Carolina, No. 14-593 (Feb. 4, 2015).

Haverkamp, R. (2002). Implementing Electronic Monitoring : A comparative, empirical study on attitudes towards the measure in Lower Saxony/Germany and in Sweden. Edition Iuscrim, Freiburg i. Br.

Hennessy-Fiske, M. (2015), Immigrants object to growing use of ankle monitors after detention. Los Angeles Crimes.Retrieved November 11, 2015, from: http://www. latimes.com/nation/immigration/ la-na-immigrant-ankle-monitors-20150802-story. html

Hilf \& Hilf, (2015). PLC. Tether and electronic monitoring devices. Law Office of Hilf and Hilf. Retrieved October 10, 2015, from: http://www.hilfandhilf.com/blog/Tetherand-Electronic-Monitoring-Devices_AE190.html

Lilly, R. (2006). Issues beyond empirical EM reports. Criminology and Public Policy, 5 (1), 93-101. doi: 10.1111/j.1745-9133.2006.00105.x.

Marsland, S. (2009). Machine learning an algorithmic perspective. Chapman \& Hall / CRC, Machine Learning \& Pattern Recognition Series. CRC Press Taylor \& Francis Group, Boca Raton, London, New York.

Gazette RS, The Law of enforcement sanctions and measures outside the prison. Retrieved December 22, 2015, from http://www.paragraf.rs/propisi/zakon_o_izvrsenju_ vanzavodskih_sankcija_i_mera.html

G4S, (2016), G4S Electronic Monitoring Services Supporting Governments In Creating Safer Communities, Expertise. Retrieved December 15, 2015, from: http:/www. au.g4s.com/media/1605/g4s-electronic-monitoring-final.pdf

Sklaver, Stacey L. (2010). The Pros and Cons of Using Electronic Monitoring Programs in Juvenile Cases. Juvenile Justice Committee Newsletter, No.5. Washington, D.C.: American Bar Association.

Smola, A., \& Vishwanathan, S. (2010). Introduction to machine learning. Cambridge University Press, United Kingdom at the University Press, Cambridge. 
Spalevic, Z., Ilic. M., \& Spalevic. P. (2015). Electronic monitoring devices and data processing. Proceedings from Synthesis: International Scientific Conference of IT and Business Related Research 2015 (pp. 242-247). Belgrade, University Singidunum. DOI: 10.15308/Synthesis-2015-242-247.

Tella, R \& Schargrodsky, E. (2009). Criminal recidivism after prison and electronic monitoring. National Bureau Of Economic Research. 1050 Massachusetts Avenue, Cambridge, MA 02138.

Tella, R., \& Schargrodsky, E. (2013). Criminal recidivism after prison and electronic monitoring. Journal of Political Economy. 121 (2), 1-43. doi:10.3386/w15602. 